\title{
Decomposition and nutrient release pattern of wheat (Triticum aestivum) residues under different treatments in desert field conditions of Sudan
}

\author{
Fatoma A. M. Rezig • Elsadig A. Elhadi • \\ Mubarak R. Abdalla
}

Received: 1 September 2013/Accepted: 22 July 2014/Published online: 15 August 2014

(C) The Author(s) 2014. This article is published with open access at Springerlink.com

\begin{abstract}
Background Recycling of crop residues is essential to sustain soil fertility and crop production. Therefore, it is of crucial importance to study the decomposition of crop residues particularly in the arid tropics. The decomposition and nutrient release pattern from crop residues incorporated in the soil have rarely been investigated under semiarid climatic conditions in Sudan. Decomposition and nutrient release pattern from wheat residue were investigated in a 12 week litter bag experiment under field condition. Litter bags contain $50 \mathrm{~g}$ wheat residue were buried in plots cultivated with guar and treated with following treatments: crop residue $(\mathrm{CR})$, recommended fertilizer + crop residue $(\mathrm{RF}+\mathrm{CR})$, sewage sludge $(\mathrm{SS})$ and non treated control (C). In each plot of each block, 12 litter bags were buried. Four bags from each treatment were retrieved at 2, 4, 6, 8, 10 and 12 weeks of decomposition. The decomposed residue was analysed for remaining dry
\end{abstract}

F. A. M. Rezig $(\varangle)$ · E. A. Elhadi

Desertification Research Institute, National Centre for Research,

Khartoum, Sudan

e-mail: fatoomaali@yahoo.com

E. A. Elhadi

e-mail: sad_agb@hotmail.com

M. R. Abdalla

Desertification and Desert Cultivation Studies Institute,

University of Khartoum, Shambat 13314, Khartoum North,

Sudan

e-mail: mubarakgeziraaba@gmail.com

Present Address:

M. R. Abdalla

Department of Soil and Environment Sciences, Faculty of Agriculture, University of Khartoum, Shambat 13314, Khartoum North, Sudan matter $(\mathrm{DM})$, nitrogen $(\mathrm{N})$, phosphorus $(\mathrm{P})$, potassium (K) calcium $(\mathrm{Ca})$, and magnesium $(\mathrm{Mg})$ contents. Mass loss and nutrients released from wheat residue followed the exponential model, $W_{t}=W_{0} \times \mathrm{e}^{-\mathrm{kt}}$ from which the specific decay rate constants $(k)$ and $t_{0.5}$ and $t_{0.95}$ were calculated.

Results The result show that the mineral fertilization combined with crop residues $(\mathrm{RF}+\mathrm{CR})$ resulted in the maximum decomposition and nutrient release compared to the other treatments. The half-life $\left(t_{0.5}\right)$ values of the treatments were in the following order: $\mathrm{RF}+\mathrm{CR}$ $(6.70$ weeks $)<$ SS $\quad(8.0$ weeks $)<\mathrm{CR} \quad(9.60$ weeks $)<\mathrm{C}$ (11.91 weeks). The percentage remaining DM in the litter bags followed the order $\mathrm{C}(73.25 \%)>\mathrm{CR} \quad(66.45$ $\%)>\mathrm{SS}(59.85 \%)>\mathrm{RF}+\mathrm{CR}(53.85 \%)$. A $50 \%$ loss of residue $\mathrm{N}$ was found after 8.88 weeks in the $\mathrm{C}$ treatment and 5.04 weeks in $\mathrm{RF}+\mathrm{CR}$ treatment. Generally, nutrient loss from all treatments in the order of $\mathrm{Mg}>\mathrm{K}=\mathrm{N}>\mathrm{Ca}>\mathrm{P}$.

Conclusions Application of mineral fertilizer or sewage sludge enhances the decomposition of low-quality residue (wheat). Therefore, it is essential to apply fertilizer in degraded soil before incorporation of crop residue with high carbon to nitrogen ratio.

Keywords Inorganic fertilizers - Mass loss · Crop residues $\cdot$ Sewage sludge

\section{Background}

Crop residues are an important source of organic nutrients, are available in large quantities, and are not being fully utilized. The economic value of crop residues mainly focuses on the equivalent fertilizer cost of the nutrients that 
they contain. Crop residue decomposition is affected by the physical and chemical characteristic of both crop residue and the soil where the crop residue is incorporated. Kriaučiūnienè et al. (2012) reported that $\mathrm{C}: \mathrm{N}$ ratio and lignin concentration are most important factors affecting the decomposition of incorporated crop residue. Swift et al. (1979) suggest that availability of soil nutrients is one of the factors affecting the rate of litter decomposition. However, reported results from the effects of increased soil $\mathrm{N}$ and $\mathrm{P}$ on the rate of litter decomposition and nutrient dynamics are inconsistent. The effect of increased soil $\mathrm{N}$ and $\mathrm{P}$ on the rate of litter decomposition varied from no effect (Hobbie and Vitousek 2000) positive effects on decomposition (Vestgarden 2001) and negative effects (Magill and Aber 1998)

Several studies have addressed litter decomposition under field conditions of humid temperate climate (Joergensen et al. 2009; Robinson et al. 1994), boreal, and wet tropical conditions (Tam et al. 1990; Saini 1989). Plurality of these studies have been carried out in forest soils under semi natural conditions (Xianiu and Hirata 2005; Alhamed et al. 2004). Fertilizer management and cultivation of different crops may have strong effects on the decomposition of plant residues, due to the difference in nutrient inputs by the fertilizers and the difference in nutrient demand by the crops.

Wheat residue used in this experiment had a low $\mathrm{N}$ content, and thus, the activity and the growth of microorganism were limited by the availability of $\mathrm{N}$. An increase in the size of the soil microbial biomass is considered essential for soil fertility improvement (Singh et al. 2006).

Kwabiah et al. (1999) found that application of fertilizer urea or triple super phosphate enhanced the decomposition of litter from Croton megalocarpus and Sesbania sesban in the early stages of decomposition compared to control. Liu et al. (2006) noted that adding $\mathrm{N}$ alone or in combination with $\mathrm{P}$ stimulated the decomposition rate of Allium bidentatum and Stipa krylovii, which can be explained by the consequent increases in the availability of $\mathrm{N}$ and $\mathrm{P}$, which are considered the main determinants of mass and nutrient loss during decomposition (Alexander 1977). As inputs of inorganic $\mathrm{N}$ or $\mathrm{P}$ increased soil $\mathrm{N}$ and $\mathrm{P}$ contents, microorganism activities may become limited more by carbon availability than by the available $\mathrm{N}$ and $\mathrm{P}$. Under such conditions, $\mathrm{C}$ may be released from the decomposing litter and used as an energy source for catabolic and anabolic activities, resulting in further increases in rates of litter breakdown (Muhammad et al. 2011).

As for biological effects on soil, application of sewage sludge increased soil microbial biomass $\mathrm{C}$ and soil respiration (an index of general metabolic activity of soil microorganisms) when compared to a control (Bhattacharyya et al. 2003). Soil enzymes are extensively used as biological assay in soil. Perucci (1990) found that after application of $75 \mathrm{Mg} \mathrm{ha}^{-1}$ of municipal sludge compost increased the enzyme activities of phosphodiesterase, alkaline phosphomonoesterase, arylsulphatase, deaminase, urease and protease.

Synchronizing soil nutrients availability with plant requirements can improve the soil-plant system, $\mathrm{N}$ use efficiency and reduce nutrients losses through leaching below the crop rooting depth and/or from gaseous emissions (Vanlauwe et al. 2001).

Litter bag method developed by Bocock and Gilbert (1957) is used to study decomposition processes of plant residues under field conditions. Although this method creates a microenvironment, it is still considered to be a useful approach, due to the relatively simple recovery of litter transferred to the field and the possibility of excluding specific fauna groups from the decomposition process (Joergensen et al. 2009; Knacker et al. 2003). Litter bags have been less intensively used in studying the decomposition of green manure and harvest residues in arable areas (Knacker et al. 2003; Berg 2000; Christensen 1985).

Decomposition and nutrient release from the crop residues with organic and inorganic fertilizers have rarely been studied in Sudan. Therefore, the objective of this research was to determine rate of decomposition and nutrient $(\mathrm{N}, \mathrm{P}$, $\mathrm{K}, \mathrm{Ca}, \mathrm{Mg}$ ) release patterns resulting from decomposition of wheat residues in a field cultivated with guar Cyamopsis tetragonoloba and treated with organic and inorganic fertilizers.

\section{Methods}

Site, soil, and climate

Field experiment to determine the decomposition of wheat residues with litter bags was carried out from June to August 2010 in the main field experiment of Omdurman Islamic University, Sudan $\left(15^{\circ} 19.9 \mathrm{~N}, 32^{\circ} 39^{\prime} \mathrm{E}\right.$, and with an elevation of $381 \mathrm{~m}$ above the sea level). The study was conducted for five seasons (wheat- guar- wheat -gaurwheat) to study the contribution of organic residues in sustaining yields of wheat (Triticum aestivum var. Imam.) and guar (Cyamopsis tetragonoloba local var.) in a crop rotation system (Rezig et al. 2013). Treatments included recommended inorganic fertilizer $92 \mathrm{~kg} \quad \mathrm{P}_{2} \mathrm{O}_{5} \mathrm{ha}^{-1}$ (204.4 kg triple super phosphate $\mathrm{ha}^{-1}$ ) and $125 \mathrm{~kg} \mathrm{~N} \mathrm{ha}^{-1}$ $\left(271.7 \mathrm{~kg}\right.$ urea ha ${ }^{-1}$ ) with crop residues $(\mathrm{RF}+\mathrm{CR})$, crop residues (CR), $10 \mathrm{t} \mathrm{ha}^{-1}$ sewage sludge (SS) and control (C). The whole plant residue was used in this study after removing the roots. The soil properties and chemical composition of wheat residue were given in Tables 1 and 2 . 


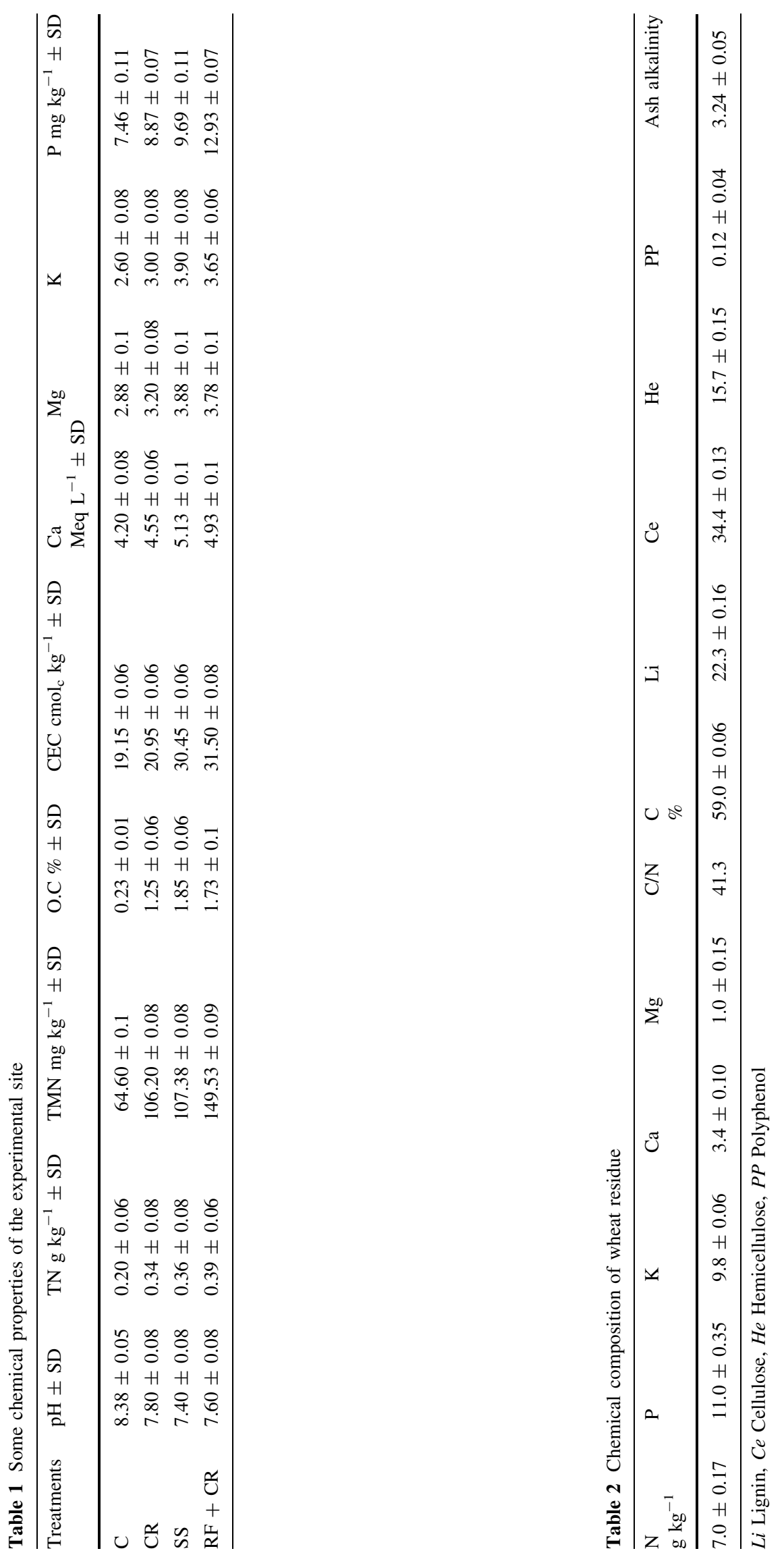


Litter bag experiment

Decomposition (mass loss) of the wheat, residues and nutrient release were monitored in the field using the litter bags method (Anderson and Ingram 1989). Nylon bags of $20 \times 10 \mathrm{~cm}$ dimensions with a mesh size of $2 \mathrm{~mm}$ were used for this study. The straw of the wheat was cut into length of about $20 \mathrm{~cm}$ and $50 \mathrm{~g}$ of oven-dried crop residues were placed into each litter bag. One side of the bag was left open for faunal activity. Ninety-six litter bags were used for this study. The litter bags from wheat residue were distributed in the control (C), crop residue at the rate of $2.5 \mathrm{t} \mathrm{ha}^{-1}(\mathrm{CR})$, recommended fertilizer + crop residue at the rate of $6.63 \mathrm{t} \mathrm{ha}^{-1}(\mathrm{RF}+\mathrm{CR})$ and sewage sludge (SS) treatment. In each plot of each block, 61 bags were buried. The litter bags were numbered and buried $5 \mathrm{~cm}$ below the ridge top to simulate residue incorporation into the plough layer. The growing guar plants were left standing for the duration of the experiment for 3 months and harvested manually in September 2010. The experiment was terminated 7 days after crop harvest. At each sampling 2, 4, 6, 8, 10 and 12 weeks after application of the residues 41 bags from each of the four treatments (16 1 bags per sampling) were retrieved and soil attached to the plant part was carefully removed. Each bag was placed inside a paper envelope and transferred to the laboratory for analysis. The content was emptied and extraneous materials, such as soil, visible animals and fine roots were removed. The decomposing crop residues were oven-dried at $65-70{ }^{\circ} \mathrm{C}$ for $48 \mathrm{~h}$ or constant weight and weighed to determine litter mass loss rates (Anderson and Ingram 1989). The remaining non-decomposed materials were ground to pass $1 \mathrm{~mm}$ sieve for chemical analysis. The ground samples were analysed for Nitrogen (Bremner and Mulvaney 1982), P, K, Ca and Mg (Chapman and Pratt 1961).

\section{Statistical analysis}

The percentage of dry mass remaining (DM) in each bag was calculated using the following equation:

$\mathrm{MR}=\left(\mathrm{W}_{t} / \mathrm{W}_{0}\right) \times 100$,

where $W_{t}=$ Weight remained after each sampling week (g) and, $W_{0}=$ Initial weight (g) which is potentially decomposable

The data for dry mass remaining from each treatment were fitted to a negative exponential model (Olson 1963): Exponential decomposition models have been extensively used to describe the decomposition of litter in litter bags (Patricio et al. 2012):

$\mathrm{W}_{t}=\mathrm{W}_{0} \mathrm{eo}^{-\mathrm{kt}}$, where $W_{0}=$ initial residue weight at time zero, $W_{\mathrm{t}}=$ litter remaining after a given time $(t), t=$ time interval of sampling expressed in weeksm, $k=$ rate constant (decomposition rate constant per week) and, $e=$ base of natural logarithms

Nutrients content $\left(\mathrm{N}, \mathrm{C}, \mathrm{P}, \mathrm{K}, \mathrm{Ca}^{2+}\right.$ and $\mathrm{Mg}^{2+}$ ) of decomposing crop residue was determined by the following equation:

\% remaining element $\left(=\left(\mathrm{W}_{t} / \mathrm{W}_{0}\right) \times\left(\mathrm{C}_{t} / \mathrm{C}_{0}\right) \times 100\right.$,

where $W_{t}$ is the remaining mass at time $t$ (in weeks), $W_{0}$ is the initial weight of the litter, $C_{t}$ is the concentration of element in decomposing litter at the time of sampling and $C_{0}$ the initial concentration of element. The regressions of $\ln \left(W_{t} / W_{0}\right)$ over time were performed separately for each set of litter bags in each plot to provide independent estimates of $k$ and $R^{2}$ for each treatment. Further, the time required for $50 \%\left(t_{0.5}\right)$ and $95 \%\left(t_{0.95}\right)$ decay was calculated as $t_{0.5}=0.693 / k$ and $t_{0.95}=3 / k$, respectively. Statistical analysis software (SAS 1985) was used to test variations between treatments and least significant difference (LSD) was used to determine differences between treatment means.

\section{Results}

Mass loss

Prior treatment of the field plots with organic and inorganic fertilizers significantly affected the amount of wheat residue lost during incorporation (Fig. 1). After 12 weeks of incorporation, wheat residue had lost 26.8, 33.6, 40.2 and $46.2 \%$ of its initial mass in the C, CR, SS and RFCR plot, respectively. The data on decomposition rate constants (k) values, $R^{2}$ and the days taken for 50 and $95 \%$ of residues to decompose $\left(t_{0.5}\right.$ and $\left.t_{0.95}\right)$ were presented in Table 3. The half-life $\left(t_{0.5}\right)$ values (i.e. the time for the wheat residue to lose half their initial mass) of the treatments were in the following order: $\mathrm{RF}+\mathrm{CR}$ $(6.70$ weeks $)<$ SS $\quad(8.0$ weeks $)<$ CR $\quad(9.60$ weeks $)<$ C (11.91 weeks). Generally, carbon decomposition followed the same trend as dry matter disappearance. The per cent DM remaining at the end of the study period was of the order: C $(73.25 \%)>\mathrm{CR}(66.45 \%)>\mathrm{SS}$ $(59.85 \%)>\mathrm{RF}+\mathrm{CR}(53.85 \%)$. The decomposition rate constant $\left(k\right.$ week $\left.^{-1}\right)$ of the treatments also showed statistical difference $(P<0.0001)$. RF $+\mathrm{CR}$ had the highest $k$ value $\left(0.104\right.$ week $\left.^{-1}\right)$ and $C$ the lowest $\left(0.057\right.$ week $\left.^{-1}\right)$. Intermediate values were recorded by SS $\left(0.087\right.$ week $\left.^{-1}\right)$ and CR $\left(0.072\right.$ week $\left.^{-1}\right)$. This means decomposition was 


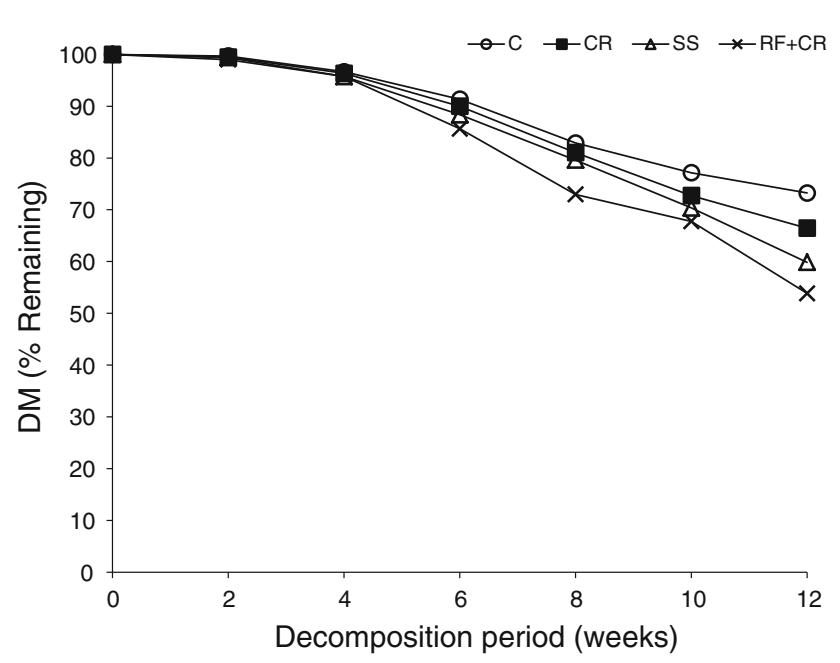

Fig. 1 Dry matter weight (DM) (\% of original content) remaining during decomposition of wheat residues

fastest in plot treated with inorganic fertilizer + crop residue $(\mathrm{RF}+\mathrm{CR})$ and slowest in untreated plots $(\mathrm{C})$.

Nutrient release pattern

Nutrient release patterns are shown in Figs. 2, 3, 4, 5 and 6. After 2 weeks of decomposition, 92.64, 94.43, 95.95 and $97.56 \%$ of the initial $\mathrm{N}$ contents remained in the $\mathrm{RF}+\mathrm{CR}, \mathrm{SS}, \mathrm{CR}$ and C treatments, respectively (Fig. 2). Fifty percentage $\mathrm{N}$ loss was attained after 5.04, 6.47, 7.53 and 8.88 weeks for RF $+\mathrm{CR}, \mathrm{SS}, \mathrm{CR}$ and C treatment, respectively, while at the end of the period, 29.81, 35.70, 46.28 and $55.98 \%$ of the initial $\mathrm{N}$ contents remained in $\mathrm{RF}+\mathrm{CR}, \mathrm{SS}, \mathrm{CR}$ and $\mathrm{C}$ treatment, respectively. The $\mathrm{RF}+\mathrm{CR}$ treatment had the highest decomposition rate constant value $\left(0.098\right.$ week $\left.^{-1}\right)$ indicating fast decomposition over all treatments.

Phosphorus release during study was shown in Fig. 3. Generally, release of $\mathrm{P}$ during the study period was slow compared to nitrogen in all treatments (Table 3). After 2 weeks, 84.94, 86.85, 95.88 and $96.75 \%$ of the initial $\mathrm{P}$ remained in the SS, RF + CR, CR and C treatments, respectively. Fifty per cent of $\mathrm{P}$ remained of the treatments were in the following order: RF $+\mathrm{CR}(8.41$ weeks $)<\mathrm{SS}$ (9.75 weeks) $<\mathrm{CR}(10.91$ weeks $)<\mathrm{C}(16.83$ weeks $)$. At the end of the study period, $37.45,41.62,48.32$ and $62.1 \%$ of the initial P contents were remaining for RF $+\mathrm{CR}, \mathrm{SS}$, $\mathrm{CR}$ and $\mathrm{C}$ treatments, respectively. The highest decomposition rate constant $\left(0.083\right.$ week $\left.^{-1}\right)$ in $\mathrm{RF}+\mathrm{CR}$ treatment indicates of fast decomposition relative to other treatments. Generally, the release of $\mathrm{K}$ in all treatments was higher than that of $\mathrm{N}$ and $\mathrm{P}$ (Table 3). The per cent of $\mathrm{K}$ that remained after 2 weeks was in the order: $\mathrm{C}$
Table 3 Decomposition constant $(K), R^{2}$, half-life $\left(t_{0.50}\right)$ and $t_{0.95}$ for nutrient loss from wheat residues

\begin{tabular}{|c|c|c|c|c|c|}
\hline Treatments & Nutrient & $K$ & $R^{2}$ & $t_{0.50}$ & $t_{0.95}$ \\
\hline \multirow[t]{6}{*}{$\mathrm{C}$} & DM & 0.057 & 0.94 & 11.91 & 52.41 \\
\hline & $\mathrm{K}$ & 0.053 & 0.84 & 13.28 & 57.45 \\
\hline & $\mathrm{N}$ & 0.048 & 0.92 & 8.88 & 38.46 \\
\hline & $\mathrm{P}$ & 0.042 & 0.98 & 16.83 & 36.14 \\
\hline & $\mathrm{Ca}$ & 0.044 & 0.99 & 15.93 & 72.85 \\
\hline & $\mathrm{Mg}$ & 0.075 & 0.97 & 9.28 & 40.18 \\
\hline \multirow[t]{6}{*}{$\mathrm{CR}$} & DM & 0.072 & 0.93 & 9.60 & 41.52 \\
\hline & K & 0.077 & 0.78 & 9.00 & 38.98 \\
\hline & $\mathrm{N}$ & 0.062 & 0.90 & 7.53 & 32.61 \\
\hline & $\mathrm{P}$ & 0.064 & 0.98 & 10.91 & 47.22 \\
\hline & $\mathrm{Ca}$ & 0.064 & 0.98 & 10.96 & 47.43 \\
\hline & $\mathrm{Mg}$ & 0.086 & 0.98 & 8.12 & 35.18 \\
\hline \multirow[t]{6}{*}{ SS } & $\mathrm{DM}$ & 0.087 & 0.92 & 8.00 & 34.58 \\
\hline & $\mathrm{K}$ & 0.110 & 0.85 & 6.30 & 27.25 \\
\hline & $\mathrm{N}$ & 0.083 & 0.89 & 6.47 & 27.96 \\
\hline & $\mathrm{P}$ & 0.073 & 0.99 & 9.75 & 41.34 \\
\hline & $\mathrm{Ca}$ & 0.081 & 0.99 & 8.60 & 37.25 \\
\hline & $\mathrm{Mg}$ & 0.142 & 0.99 & 4.90 & 21.20 \\
\hline \multirow[t]{6}{*}{$\mathrm{RF}+\mathrm{CR}$} & DM & 0.104 & 0.92 & 6.70 & 28.99 \\
\hline & $\mathrm{K}$ & 0.126 & 0.88 & 5.51 & 23.84 \\
\hline & $\mathrm{N}$ & 0.098 & 0.91 & 5.04 & 21.82 \\
\hline & $\mathrm{P}$ & 0.083 & 0.99 & 8.41 & 36.38 \\
\hline & $\mathrm{Ca}$ & 0.094 & 0.98 & 7.37 & 31.92 \\
\hline & $\mathrm{Mg}$ & 0.170 & 0.98 & 4.14 & 17.91 \\
\hline \multirow[t]{6}{*}{ Probability } & DM & 0.0001 & - & 0.0001 & 0.0001 \\
\hline & $\mathrm{K}$ & 0.0001 & - & 0.0001 & 0.0001 \\
\hline & $\mathrm{N}$ & 0.0001 & - & 0.0001 & 0.0001 \\
\hline & $\mathrm{P}$ & 0.0001 & - & 0.0001 & 0.0001 \\
\hline & $\mathrm{Ca}$ & 0.0001 & - & 0.0001 & 0.0001 \\
\hline & $\mathrm{Mg}$ & 0.0001 & - & 0.0001 & 0.0001 \\
\hline
\end{tabular}

$(97.66 \%)>\mathrm{CR}(96.45 \%)>\mathrm{SS}(93.28 \%)>\mathrm{RF}+\mathrm{CR}$ $(92.18 \%)$ (Fig. 4). Fifty per cent of $\mathrm{K}$ remained from wheat residue were in the following order: $\mathrm{RF}+\mathrm{CR}$ (5.51 weeks) $<$ SS $(6.30$ weeks $)<$ CR $(9.00$ weeks $)<$ C (13.28 weeks). At the end of the study period, 21.02, 23.97, 34.75 and $50.08 \%$ of the initial $\mathrm{K}$ content were remaining in $\mathrm{RF}+\mathrm{CR}, \mathrm{SS}, \mathrm{CR}$ and $\mathrm{C}$ treatment, respectively.

Treatments significantly increased the decomposition rate of both $\mathrm{Ca}$ and $\mathrm{Mg}$ from wheat residue. The release of $\mathrm{Ca}$ was slow in all the treatments compared to other nutrients (Table 3). RF + CR treatment decomposed $50 \%$ of its initial $\mathrm{Ca}$ and $\mathrm{Mg}$ content at the 7.37, and 4.41 weeks, respectively. At week 12, 60.86, 48.86, 38.73 and $33.26 \%$ of the initial Ca contents were remaining in $\mathrm{C}, \mathrm{CR}$, SS and $\mathrm{RF}+\mathrm{CR}$ treatments, respectively (Fig. 5). After 2 weeks, the $\mathrm{Mg}$ remaining in $\mathrm{RF}+\mathrm{CR}$ treatment $(89.11 \%)$ was 


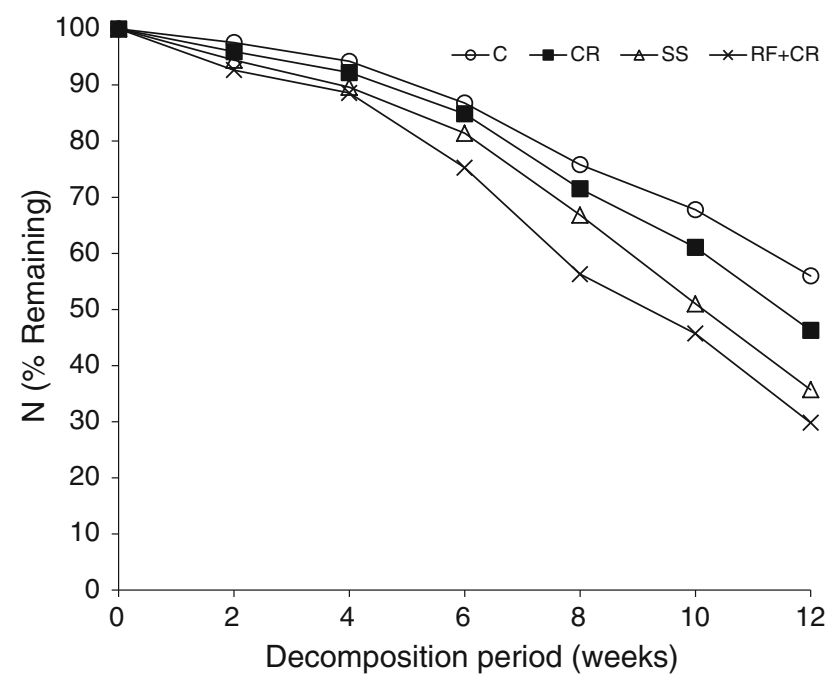

Fig. 2 Nitrogen remaining (\% of original contents) during decomposition of wheat residues

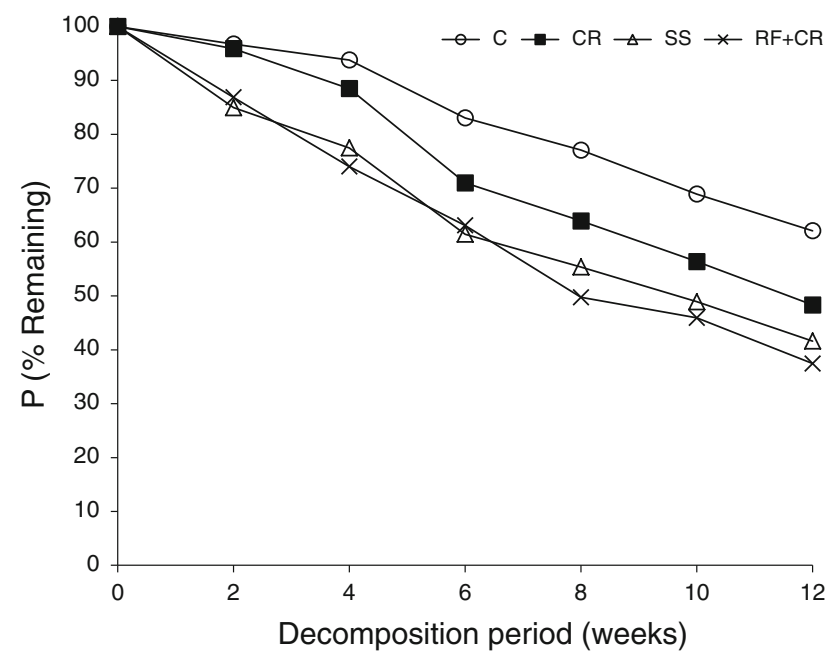

Fig. 3 Phosphorous remaining (\% of original contents) during decomposition of wheat residues

significantly $(P \leq 0.0002)$ lower than that in all treatments. The half-life $\left(t_{0.5}\right)$ values of the treatments were in the following order: RF + CR $(4.14$ weeks $)<\mathrm{SS}$ (4.9 weeks) $<\mathrm{CR}(8.12$ weeks $)<\mathrm{C} \quad(9.28$ weeks $)$. The per cent $\mathrm{Mg}$ remaining (Fig. 6) at the end of the study period was at the order of $\mathrm{C}(43.95 \%)>\mathrm{CR}$ $(38.22 \%)>\mathrm{SS}(19.90 \%)>\mathrm{RF}+\mathrm{CR}(14.81 \%)$; the decomposition rate constant $\left(k\right.$ week $\left.^{-1}\right)$ of the treatments also showed statistical difference $(P<0.0001)$. RF $+\mathrm{CR}$ treatment had the highest $k$ value $\left(0.170\right.$ week $\left.^{-1}\right)$ and $C$ had the lowest $\left(0.075\right.$ week $\left.^{-1}\right)$. SS $\left(0.142\right.$ week $\left.^{-1}\right)$ and CR recorded intermediate values $\left(0.086\right.$ week $\left.^{-1}\right)$. This means

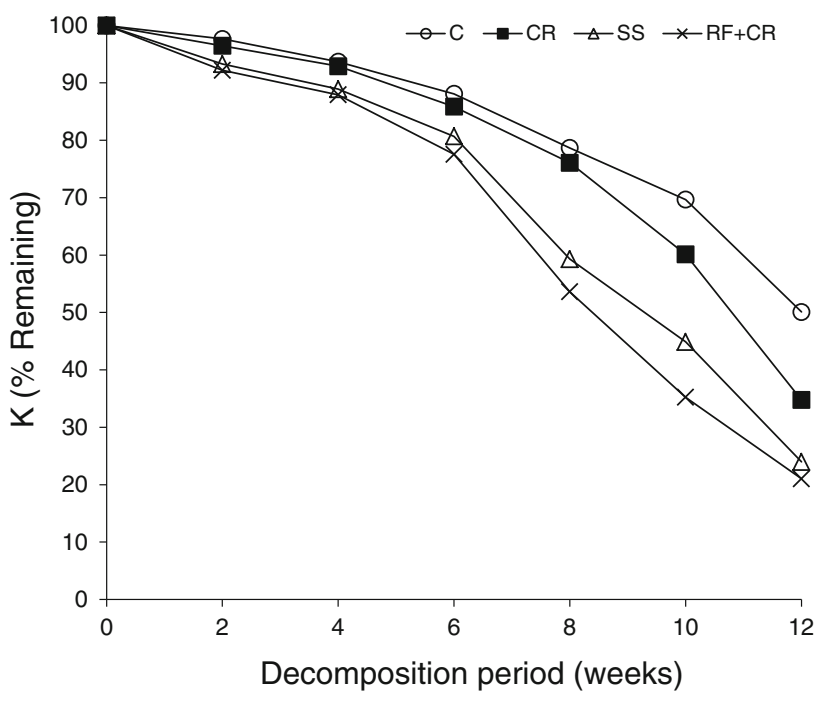

Fig. 4 Potassium remaining (\% of original content) during decomposition of wheat residues

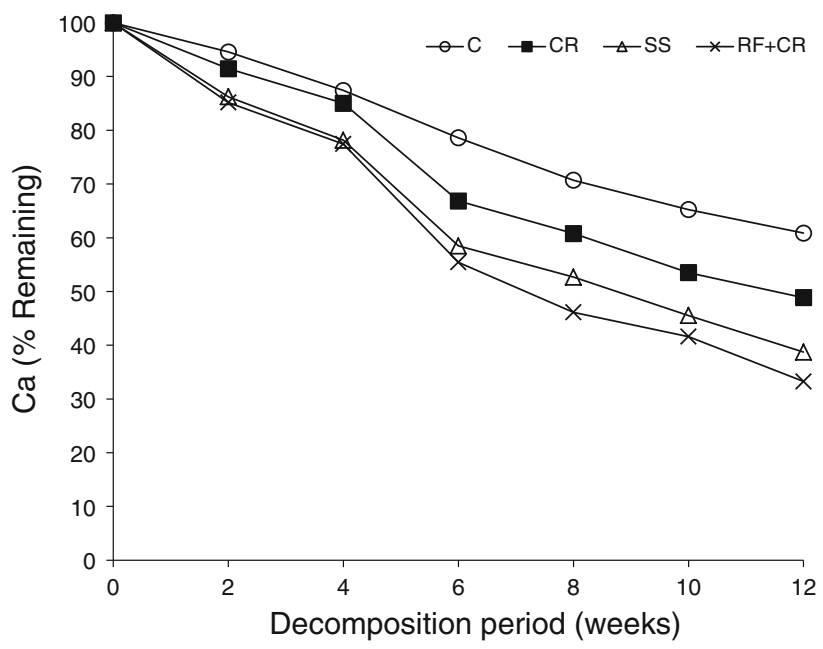

Fig. 5 Calcium remaining (\% of original contents) during decomposition of wheat residues

decomposition was fastest for $\mathrm{RF}+\mathrm{CR}$ and slowest for $\mathrm{C}$ treatments.

\section{Discussion}

Incorporation of crop residue with or without fertilizer and sewage sludge significantly changed soil physicochemical properties (Rezig et al. 2013). The decomposition rate of wheat residue increased with the increase in $\mathrm{N}$ and $\mathrm{P}$ content in the soil. The initial $\mathrm{N}$ and $\mathrm{P}$ concentration in the plots was in the following order: $\mathrm{RFCR}>\mathrm{SS}>\mathrm{CR}<\mathrm{C}$ 


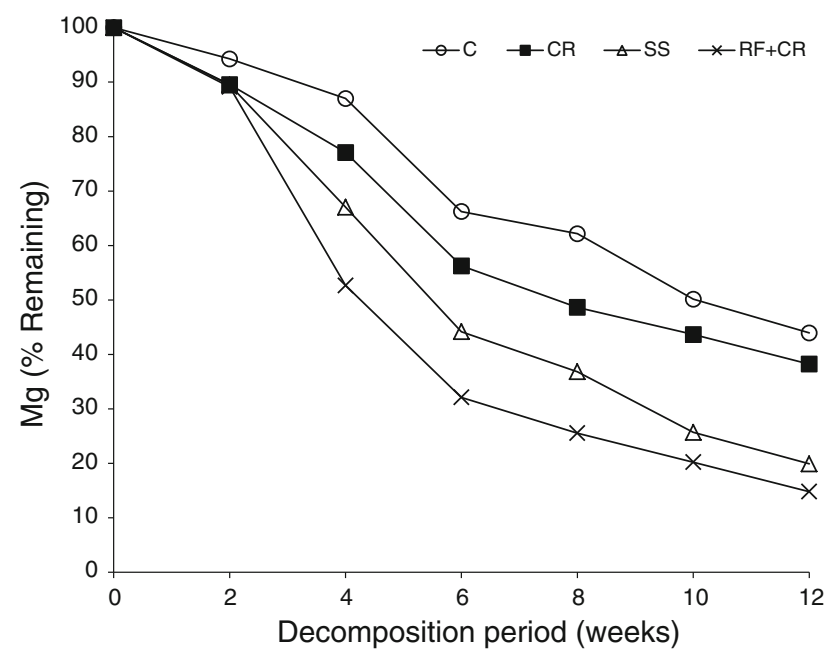

Fig. 6 Magnesium remaining (\% of original contents) during decomposition of wheat residues

(Table 1). The increase in the decomposition of wheat residue with the increase in soil nutrients is consistent with previous study report that increase in nutrient supply ( $\mathrm{N}$ and $\mathrm{P}$ ) increased litter decomposition (Thirukkumaran and Paskinson 2002). The decomposition of plant litter is limited by the concentration of inorganic $\mathrm{N}$ and $\mathrm{P}$ (Alexander 1977). The increase in decomposition of wheat residue may be attributed to the increase in microbial biomass and efficiency (Thirukkumaran and Paskinson 2002; Qualls and Richardson 2000); increase in degradation of cellulose (Sinsabaugh et al. 2002); change in soil microorganisms community; increase in microbial activity (Gulis and Suberkropp 2003) and increase in extracellular enzymes such as Urease, acid phosphatase and glycosidase in the soil and in the litter (Saiya-Cork et al. 2002). However, the finding of the current study is in contrast with result reported by Chen et al. (2013). They reported that addition $\mathrm{N}$ and $\mathrm{P}$ decreased litter decomposition. They attributed the negative effect of $\mathrm{N}$ addition on litter decomposition to related high $\mathrm{N}$-saturation in the soil and the negative effect of $\mathrm{P}$ addition to the suppression of microbial $\mathrm{P}$ mining. Knorr et al. (2005) concluded that $\mathrm{N}$ addition may stimulate litter decomposition in $\mathrm{N}$-limited forest, but inhibit litter decomposition in $\mathrm{N}$-rich forest.

Pernin et al. (2006) reported that application of sewage sludge increased mesofauna population in treated plots. Similarly, Bhattacharyya et al. (2003) found that application of sewage sludge increased soil microbial biomass $\mathrm{C}$ and soil respiration when compared to a control. Application of $75 \mathrm{Mg} \mathrm{ha}^{-1}$ of municipal sludge compost increased the activity of enzyme such as phosphodiesterase, alkaline phosphomonoesterase, arylsulphatase, deaminase, urease and protease (Perucci 1990).
The lower nitrogen remaining from incorporated wheat residue in $\mathrm{RF}+\mathrm{CR}$ and $\mathrm{SS}$ treatment compared to $\mathrm{Cr}$ and $\mathrm{C}$ treatment might be attributed to their higher $\mathrm{N}$ content (Table 1). Increase in soil $\mathrm{N}$ improved the activities of microorganisms, which enhanced the transformation process in soil including the decomposition of plant residues and accumulation of $\mathrm{N}$ in the soil (Bhattacharyya et al. 2008; Anwar et al. 2005). Addition of $\mathrm{N}$ to the soil accelerates the decomposition and release of nutrients from material with high C:N ratio (Sinsabaugh et al. 2002). The release of $\mathrm{P}$ from wheat residue increased with the increase in the soil $\mathrm{P}$ in the soil. This result was similar to the pattern of $\mathrm{N}$ released.

Fertilization with sewage sludge or crop residue with fertilizer significantly $(P<0.0001)$ enhances $\mathrm{K}$ decomposition. The fast release of $\mathrm{K}$ in all treatment relative to other nutrient may be attributed to its existence in the cell fluid as non structural components (Christensen 1985). Similar results were reported by Mubarak et al. (2002); Attiwell (1968); Christensen (1985).

Similar trend was observed for the release of $\mathrm{Ca}$ and $\mathrm{Mg}$. The release of $\mathrm{Ca}$ and $\mathrm{Mg}$ is related to mass loss trend. Therefore, increase in mass loss with the increase in nutrient content in the soil resulted in increase in $\mathrm{Ca}$ and $\mathrm{Mg}$ decomposition rate from wheat residue. Hodges (2010), Demarty et al. (1984) suggest that Ca is structural component of plant cell.

\section{Conclusions}

Soil nutrient contents have strong effects on the decomposition of low-quality residue (wheat residue). Mineral fertilization combined with crop residues significantly enhanced decomposition and nutrient release. Application of $\mathrm{N}$ and $\mathrm{P}$ is important management practice to enhance the decomposition of high $\mathrm{C}: \mathrm{N}$ ratio crop residue in the field.

Acknowledgements This work is financially supported by the National Center for Research, Ministry of Science and Technology. The authors are grateful to Dr. Abdelbagi Ahmed Abdelbagi, Department of Agronomy, Faculty of Agriculture, Omdurman Islamic University for using the experimental farm. We also thank Dr. Awad Galal from the Department of Biofertilization, Ministry of Science and Technology, Sudan for supplying us with the inoculums. The authors are also grateful to the technicians of the laboratory of the department of soil and environment sciences, University of Khartoum, Sudan for their help and encouragement during analysis

Author contributions Rezig F.A.M she is the main author and did the field and laboratory work and drafted the manuscript. Elhadi, E.A participates in several field works, statistical analysis and participates in correction of the manuscript. Mubarak, A. R $\mathrm{He}$ is the main supervisor and drafts the proposal and participates in the correction of the manuscript. All authors read and confirmed the final manuscript. 
Open Access This article is distributed under the terms of the Creative Commons Attribution License which permits any use, distribution, and reproduction in any medium, provided the original author(s) and the source are credited.

\section{References}

Alexander ML (1977) Introduction to soil microbiology. Wiley, New York

Alhamed L, Arakaki S, Hagihara A (2004) Decomposition of leaf litter of four tree species in a subtropical evergreen broad-leaved forest Okinawa Island. Japan. For Ecol Manag 202:1-11

Anderson JM, Ingram JSI (1989) Tropical soil biology and fertility. A handbook of methods. CAB International, Aberystwyth

Anwar M, Patra DD, Chand S, Alpesh K, Naqvi AA, Khanuja PS (2005) Effect of organic manures on growth, herb and oil yield, nutrient accumulation, and oil quality of French basil. Commun Soil Sci Plant Anal 36:1737-1746

Attiwell PM (1968) The loss of elements from decomposing litter. Ecology 49:142-145

Berg B (2000) Litter decomposition and organic matter turnover in northern forest soils. Ecol Manag 133:13-22

Bhattacharyya P, Chakrabarti K, Chakraborty A (2003) Effect of MSW compost on microbiological and biochemical soil quality indicators. Compost Sci Util 11(3):220-227

Bhattacharyya R, Kundu S, Prakash V, Gupta HS (2008) Sustainability under combined application of mineral and organic fertilizers in a rain fed soybean-wheat system of the Indian Himalayas. Eur J Agron 28:33-46

Bocock KL, Gilbert O (1957) The disappearance of leaf litter under different woodland conditions. Plant Soil 9:179-185

Bremner JM, Mulvaney CS (1982) Nitrogen total. In: Page AL (ed) Methods of soil analysis. Agron. No. 9. Part 2: chemical and microbiological properties, 2nd edn edn. Am Soc Agron, Madison, pp 595-624

Chapman HD, Pratt PF (1961) Methods of analysis for soil, plant and water. University of California Riverside

Christensen BT (1985) Wheat and barley straw decomposition under field conditions: effect of soil type and plant cover on weight loss, nitrogen and potassium content. Soil Biol Biochem 17:691-697

Demarty M, Morvan C, Thellier M (1984) Calcium and the cell wall. Plant Cell Environ 7:441-448

Gulis V, Suberkropp K (2003) Leaf litter decomposition and microbial activity in nutrient-enriched and unaltered reaches of a headwater stream. Freshw Biol 48:123-134

Hobbie SE, Vitousek PM (2000) Nutrient regulation of decomposition in Hawaiian montane forests: do the same nutrients limit production and decomposition? Ecology 81:1867-1877

Hodges SC (2010) Soil fertility basics, soil science extension. North Carolina State University, Raleigh

Joergensen RG, Scholle GA, Wolters V (2009) Dynamics of mineral components in the forest floor of an acidic beech (Fagus sylvatica L.) forest. Eur J Soil Biol 45:285-289

Knacker T, Förster B, Römke J, Framptom G (2003) Assessing the effects of plant protection on organic matter breakdown in arable fields-litter decomposition test systems. Soil Biol Biochem 35:1269-1287

Kriaučiūnienè Z, Velička R, Raudonius S (2012) The influence of crop residues type on their decomposition rate in the soil: a litter bag study. Žemdirbyste Agriculture 99(3):227-236

Kushwaha CP, Tripathi SK, Singh KP (2000) Variations in soil microbial biomass and $\mathrm{N}$ availability due to residue and tillage management in a dry land rice agroecosystem. Soil Tillage Res $56: 153-166$

Kwabiah AB, Voroney RP, Palm CA, Stoskpf NC (1999) Inorganic fertilizer enrichment of soil: effect on decomposition of plant litter under sub-humid tropical conditions. Biol Fertil Soils 30:224-231

Liu P, Huang JH, Han XG, Sun OJ, Zhou Z (2006) Differential responses of litter decomposition to increased soil nutrients and water between two contrasting grassland plant species of Inner Mongolia, China. Appl Soil Ecol 34:266-275

Magill AH, Aber JD (1998) Long-term effects of experimental nitrogen additions on foliar litter decay and humus formation in forest ecosystems. Plant Soil 203:301-311

Mubarak AR, Rosenani AB, Zauyah SD, Anuar AR (2000) Decomposition and nutrient release from Maize (Zea mays L.) residues and $\mathrm{N}$ uptake by groundnut (Arachis hypogea). J Soil Sci 3:93-107

Mubarak AR, Rosenani AB, Anuar AR, Zauyah S (2002) Decomposition and nutrient release of maize stover and groundnut haulm under tropical field conditions of Malaysia. Commun Soil Sci Plant Anal 33(3):609-622

Muhammad W, Sarah M, Vaughan SM, Dalal RC, Menzies NW (2011) Crop residues and fertilizer nitrogen influence residue decomposition and nitrous oxide emission from a Vertisol. Biol Fertil Soils 47:15-23

Olson JS (1963) Energy storage and the balance of producers and decomposers in ecological systems. Ecology 44:322-331

Patricio MS, Nunes LF, Pereira EL (2012) Litterfall and litter decomposition in chestnut high forest stands in northern Portugal. For Syst 21(2):259-271

Pernin C, Cortet J, Joffre R, Le Petit J, Torre F (2006) Sewage sludge effects on mesofauna and cork oak (Quercus suber L.) leaves decomposition in a Mediterranean forest firebreak. J Environ Qual 35:2283-2292

Perucci P (1990) Effect of the addition of municipal soild-waste compost on microbial biomass and enzyme activities in soil. Biol Fertil Soils 10:221-226

Qualls RG, Richardson CJ (2000) Phosphorus enrichment affects litter decomposition, immobilization, and soil microbial phosphorus in wetland mesocosms. Soil Sci Soc Am J 64:799-808

Rezig FAM, Elhadi EA, Mubarak AR (2013) Impact of organic residues and mineral fertilizer application on soil-crop systems I: yield and nutrients content. Arch Agron Soil Sci 59(9): $1229-1243$

Robinson CH, Dighton J, Frankland JC, Roberts JD (1994) Fungal communities on decaying wheat straw of different resource qualities. Soil Biol Biochem 26:1053-1058

Saini RC (1989) Mass loss and nitrogen concentration changes during the decomposition of rice residues under field conditions. Pedobiologia 33:229-235

Saiya-Cork KR, Sinsabaugh RL, Zak DR (2002) The effects of long term nitrogen deposition on extracellular enzyme activity in an Acer saccharum forest soil. Soil Biol Biochem 34:1309-1315

SAS (1985) SAS user's guide: statistics, 5th edn. SAS Institute, Cary

Singh S, Ghoshal N, Singh KP (2006) Variations in soil microbial biomass and crop roots due to differing resource quality inputs in a tropical dry land agroecosystem. Soil Biol Biochem 17:547-551

Sinsabaugh RL, Carreiro MM, Repert DA (2002) Allocation of extracellular enzymatic activity in relation to litter composition, $\mathrm{N}$ deposition, and mass loss. Biogeochemistry 60:1-24

Swift MJ, Heal OW, Anderson JM (1979) Decomposition in terrestrial ecosystems. University of California press, Berkley

Tam NFY, Vrijmoed LLP, Wonf YS (1990) Nutrient dynamics associated with leaf decomposition in a small subtropical mangrove community in Hong Kong. Bull Mar Sci 47:68-78 
Thirukkumaran CM, Parkinson D (2002) Microbial activity, nutrient dynamics and litter decomposition in a Canadian Rocky Mountain pine forest as affected by $\mathrm{N}$ and $\mathrm{P}$ fertilizers. For Ecol Manage 159:187-201

Vanlauwe B, Wendt J, Diels J (2001) Combined application of organic matter and fertilizer. In: Tian G, Ishida F, Keatinge JDH (eds) Sustaining soil fertility in West Africa. Soil Science Society of America and American Society of Agronomy, Madison, pp 247-279
Vestgarden LS (2001) Carbon and nitrogen turnover in the early stage of Scots pine (Pinus sylvestris L.) needle litter decomposition: effects of internal and external nitrogen. Soil Biol Biochem 33:465-474

Xianiu X, Hirata E (2005) Decomposition patterns of leaf litter of seven common canopy species in a subtropical forest: $\mathrm{N}$ and $\mathrm{P}$ dynamics. Plant Soil 273:279-289 